\title{
MERS Coronavirus: An Emerging Zoonotic Virus
}

\author{
Fang $\mathrm{Li}^{1, *}$ and Lanying $\mathrm{Du}^{2, *}$ \\ 1 Department of Veterinary and Biomedical Sciences, College of Veterinary Medicine, University of Minnesota, \\ Saint Paul, MN 55108, USA \\ 2 Lindsley F. Kimball Research Institute, New York Blood Center, New York, NY 10065, USA \\ * Correspondence: lifang@umn.edu (F.L.); ldu@nybc.org (L.D.); \\ Tel.: +1-612-625-6149 (F.L.); +1-212-570-3459 (L.D.)
}

Received: 16 July 2019; Accepted: 17 July 2019; Published: 19 July 2019

check for updates

Middle East respiratory syndrome coronavirus (MERS-CoV) is an emerging virus that was first reported in humans in June 2012 [1]. To date, MERS-CoV continues to infect humans with a fatality rate of $\sim 35 \%$. At least 27 countries have reported human infections with MERS-CoV (https://www.who.int/emergencies/mers-cov/en/). MERS-CoV is a zoonotic virus. Like severe acute respiratory syndrome coronavirus (SARS-CoV), MERS-CoV is believed to have originated from bats [2,3]. However, whereas the bat-to-human transmission of SARS-CoV was likely mediated by palm civets as intermediate hosts, humans likely acquired MERS-CoV from dromedary camels [4-6]. Human-to-human transmission of MERS-CoV does occur, but it is limited mostly to health care environments [7,8]. Moreover, whereas SARS-CoV recognizes angiotensin-converting enzyme 2 (ACE2) as a cellular receptor $[9,10]$, MERS-CoV uses dipeptidyl peptidase 4 (DPP4) to enter target cells [11,12]. Currently, no vaccines or antiviral therapeutics have been approved for the prevention or treatment of MERS-CoV infection, although a number of them have been developed preclinically and/or tested clinically [13-16].

The articles in this special issue of Viruses were written by researchers working in the MERS-CoV field. The main aims of this issue are to (i) better understand MERS-CoV transmission, epidemiology, and pathogenesis; (ii) summarize current progress on MERS-CoV animal models, vaccines, and therapeutics; and (iii) discuss future prospects for MERS-CoV research. This issue includes seven review articles and nine original research papers, each providing detailed updates on current MERS-CoV studies.

Studies on the transmission, epidemiology, and pathogenesis of MERS-CoV form one of the foundations of MERS-CoV research. In this issue, Farag and colleagues summarize the possible drivers of the emergence of MERS-CoV and its spillover to humans in Qatar, explaining the potential reasons for the camel-to-human transmission of MERS-CoV [17]. The review article by Song and colleagues provides an overall description of the epidemiology, pathogenesis, and other important aspects of MERS-CoV [18]. Widagdo and colleagues review the host determinants of the transmission and pathogenesis of MERS-CoV, indicating that receptor DPP4 plays an important role in these processes [19]. A research article by Yan and colleagues characterizes the role of lipid profiles in the pathogenesis and infectivity of human coronaviruses, including MERS-CoV, suggesting that lipid metabolism may be involved in the propagations of these coronaviruses [20]. These reports provide insights into how MERS-CoV infects cells and spreads within and across host species. They have also laid the foundations for developing animal models.

Animal models are essential tools for the preclinical evaluation of anti-MERS-CoV countermeasures. Dromedary camels, alpacas, and non-human primates are susceptible to MERS-CoV infection [21-23]; however, the virus does not infect small animals such as mice, hamsters, and ferrets [24-26]. Several mouse models that express human DPP4 (hDPP4) have been established for MERS-CoV infection [27-29]. In this issue, Widagdo and colleagues examine rabbits as potential hosts for MERS-CoV, showing that MERS-CoV infects rabbits without causing symptoms; they also analyze the route of MERS-CoV 
transmission in rabbits [30]. Fan and colleagues report the development of an hDPP4-expressing mouse model through inserting hDPP4 gene into a constitutive and ubiquitous gene expression locus using CRISPR/Cas9 technology. This mouse model is susceptible to MERS-CoV infection [31]. These articles have established platforms for testing vaccines and therapeutic agents targeting MERS-CoV.

Effective vaccines are essential for preventing MERS-CoV infection. The MERS-CoV surface spike (S) protein is a key target for vaccine design [14]. The $S$ protein comprises two subunits: the S1 subunit is responsible for binding to the DPP4 receptor via a receptor-binding domain (RBD), and the S2 subunit mediates virus-host membrane fusion [32-35]. Several MERS-CoV S protein-based vaccines have been developed; when tested in animal models, they showed protective efficacy against MERS-CoV [14]. In this issue, Schindewolf and Menachery summarize the progress of MERS-CoV S-protein-based vaccine development and also describe potential challenges [36]. Zhou and colleagues review current advances in RBD-based MERS-CoV vaccines [37]. A research paper by Adney and colleagues evaluates the efficacy of a MERS-CoV S1 subunit vaccine aided by adjuvants; the authors report reduced and delayed viral shedding in dromedary camels as well as the complete protection of alpacas from MERS-CoV infection [38]. This and other studies demonstrate that the protective efficacy of MERS vaccines positively correlates with neutralizing antibody titers in serum [38,39]. In addition to inducing neutralizing antibodies, some types of vaccines can induce cellular immune responses against MERS-CoV. Other than the $\mathrm{S}$ protein, structural proteins such as the nucleocapsid $(\mathrm{N})$ protein may also serve as vaccine targets. Here, Veit and colleagues report that a MERS-CoV N protein-based vaccine, which is delivered through a modified Vaccinia virus, induces $\mathrm{CD} 8^{+} \mathrm{T}$ cell responses in a mouse model; they further identify a MERS-CoV N protein-specific $\mathrm{CD}^{+} \mathrm{T}$ cell epitope on the vaccine [40]. Overall, these reports demonstrate that a variety of promising vaccine tools are available to prevent MERS-CoV infection in humans and other animals.

Therapeutics are critical tools for treating MERS-CoV infection. Again, the MERS-CoV S protein is an important target for therapeutic development [16]. MERS-CoV S2 contains two heptad repeat regions, HR1 and HR2, that are critical for $S$ protein-mediated membrane fusion [34]. Hence, peptides mimicking HR1 or HR2 may interfere with the viral membrane-fusion process [34]. Moreover, RBD-targeting neutralizing monoclonal antibodies (mAbs) can block the viral attachment step [37]. In addition to conventional $\mathrm{mAbs}$, single-domain antibodies isolated from camelids, called nanobodies (Nbs), can also block RBD/receptor interactions; these $\mathrm{Nbs}$ have been gaining popularity as therapeutic agents due to their small size and high stability [41,42]. Thus, both the HR1/HR2 peptide mimics and RBD-targeting mAbs and Nbs may serve as MERS-CoV entry inhibitors. Furthermore, small molecules targeting the $S$ protein or nonstructural proteins may serve as therapeutic alternatives to peptide mimics and antibodies [16,43]. In this issue, two review articles report the current advances in therapeutic neutralizing antibodies, one by Han and colleagues and the other by Zhou and colleagues $[37,44]$. The latter article also discusses potential strategies and challenges to improving the efficacy of therapeutic neutralizing antibodies. In a research article, He and colleagues describe the construction and expression of dimeric and trimeric Nbs that target MERS-CoV RBD and further demonstrate the strong stability and high neutralizing activity of these Nbs against multiple MERS-CoV strains [42]. In another research article, $\mathrm{Xia}$ and colleagues report that three peptides mimicking HR2 from HKU4 (which is a MERS-related coronavirus from bats) strongly inhibit MERS-CoV infection [45]. Interestingly, Wang and colleagues report that the combination of a MERS-CoV HR2 peptide mimic and an RBD-targeting neutralizing $\mathrm{mAb}$ demonstrate potent synergistic effects in inhibiting MERS-CoV $S$ protein-mediated viral entry [46]. In another research article, Jiang and colleagues report that an antibody targeting complement receptor C5aR1 inhibits MERS-CoV infection, indicating that MERS-CoV infection elicits the over-activation of the complement system, and this process can be blocked by anti-C5aR1 antibodies [47]. Moreover, Liang and colleagues review advances in the development of small-molecular MERS-CoV inhibitors [48]. Overall, these articles confirm that anti-MERS-CoV therapeutics have great potentials in treating MERS-CoV infections in humans and other animals. 
To summarize, significant progress has been made in MERS-CoV research in the past seven years since the virus was discovered. This progress includes, but is not limited to, the epidemiology, transmission, and pathogenesis of MERS-CoV, as well as animal models, vaccines, and antivirals for MERS-CoV. This special issue of Viruses provides updated reports on this progress. However, challenges remain. For example, we still do not understand how exactly MERS-CoV transmits from bats to camels or humans. Moreover, compared to HIV and influenza viruses, the potential market for MERS-CoV vaccines and therapeutics is much smaller, making commercialization of MERS-related products more challenging. Nevertheless, the past two decades have witnessed the emergence of two highly pathogenic coronaviruses, MERS-CoV and SARS-CoV. While these two viruses remain significant threats to global health, future novel coronaviruses with pandemic potential may emerge from their animal reservoirs and infect humans. Thus, research into MERS-CoV should remain a high priority for the virology community. In fact, the impressive progress in MERS-CoV research has benefitted tremendously from previous research into coronaviruses including SARS-CoV. Therefore, scientists' current efforts regarding MERS-CoV will prepare humans to battle any future novel coronaviruses with pandemic potential.

Acknowledgments: Our studies are supported by the NIH grants (R01AI139092, R01AI137472, R01AI089728, and R01AI110700). We would like to thank all authors and reviewers for their contributions to this special issue of Viruses.

Conflicts of Interest: We declare no competing interests.

\section{References}

1. Zaki, A.M.; van Boheemen, S.; Bestebroer, T.M.; Osterhaus, A.D.; Fouchier, R.A. Isolation of a novel coronavirus from a man with pneumonia in Saudi Arabia. N. Engl. J. Med. 2012, 367, 1814-1820. [CrossRef] [PubMed]

2. Yang, Y.; Du, L.; Liu, C.; Wang, L.; Ma, C.; Tang, J.; Baric, R.S.; Jiang, S.; Li, F. Receptor usage and cell entry of bat coronavirus HKU4 provide insight into bat-to-human transmission of MERS coronavirus. Proc. Natl. Acad. Sci. USA 2014, 111, 12516-12521. [CrossRef] [PubMed]

3. Wang, L.F.; Shi, Z.; Zhang, S.; Field, H.; Daszak, P.; Eaton, B.T. Review of bats and SARS. Emerg. Infect. Dis. 2006, 12, 1834-1840. [CrossRef]

4. Du, L.; He, Y.; Zhou, Y.; Liu, S.; Zheng, B.J.; Jiang, S. The spike protein of SARS-CoV-a target for vaccine and therapeutic development. Nat. Rev. Microbiol. 2009, 7, 226-236. [CrossRef] [PubMed]

5. Alshukairi, A.N.; Zheng, J.; Zhao, J.; Nehdi, A.; Baharoon, S.A.; Layqah, L.; Bokhari, A.; Al Johani, S.M.; Samman, N.; Boudjelal, M.; et al. High prevalence of MERS-CoV infection in camel workers in Saudi Arabia. MBio 2018, 9, e01985-18. [CrossRef] [PubMed]

6. Haagmans, B.L.; Al Dhahiry, S.H.; Reusken, C.B.; Raj, V.S.; Galiano, M.; Myers, R.; Godeke, G.J.; Jonges, M.; Farag, E.; Diab, A.; et al. Middle East respiratory syndrome coronavirus in dromedary camels: An outbreak investigation. Lancet Infect. Dis. 2014, 14, 140-145. [CrossRef]

7. Hunter, J.C.; Nguyen, D.; Aden, B.; Al, B.Z.; Al, D.W.; Abu, E.K.; Khudair, A.; Al, M.M.; El, S.F.; Imambaccus, H.; et al. Transmission of Middle East respiratory syndrome coronavirus infections in healthcare settings, Abu Dhabi. Emerg. Infect. Dis. 2016, 22, 647-656. [CrossRef] [PubMed]

8. Oboho, I.K.; Tomczyk, S.M.; Al-Asmari, A.M.; Banjar, A.A.; Al-Mugti, H.; Aloraini, M.S.; Alkhaldi, K.Z.; Almohammadi, E.L.; Alraddadi, B.M.; Gerber, S.I.; et al. 2014 MERS-CoV outbreak in Jeddah—A link to health care facilities. N. Engl. J. Med. 2015, 372, 846-854. [CrossRef]

9. Li, F.; Li, W.; Farzan, M.; Harrison, S.C. Structure of SARS coronavirus spike receptor-binding domain complexed with receptor. Science 2005, 309, 1864-1868. [CrossRef]

10. Li, W.; Moore, M.J.; Vasilieva, N.; Sui, J.; Wong, S.K.; Berne, M.A.; Somasundaran, M.; Sullivan, J.L.; Luzuriaga, K.; Greenough, T.C.; et al. Angiotensin-converting enzyme 2 is a functional receptor for the SARS coronavirus. Nature 2003, 426, 450-454. [CrossRef]

11. Raj, V.S.; Mou, H.; Smits, S.L.; Dekkers, D.H.; Muller, M.A.; Dijkman, R.; Muth, D.; Demmers, J.A.; Zaki, A.; Fouchier, R.A.; et al. Dipeptidyl peptidase 4 is a functional receptor for the emerging human coronavirus-EMC. Nature 2013, 495, 251-254. [CrossRef] [PubMed] 
12. Li, F. Receptor recognition mechanisms of coronaviruses: A decade of structural studies. J. Virol. 2015, 89, 1954-1964. [CrossRef] [PubMed]

13. Haagmans, B.L.; van den Brand, J.M.; Raj, V.S.; Volz, A.; Wohlsein, P.; Smits, S.L.; Schipper, D.; Bestebroer, T.M.; Okba, N.; Fux, R.; et al. An orthopoxvirus-based vaccine reduces virus excretion after MERS-CoV infection in dromedary camels. Science 2016, 351, 77-81. [CrossRef] [PubMed]

14. Zhou, Y.; Jiang, S.; Du, L. Prospects for a MERS-CoV spike vaccine. Expert Rev. Vaccines 2018, 17, $677-686$. [CrossRef] [PubMed]

15. Beigel, J.H.; Voell, J.; Kumar, P.; Raviprakash, K.; Wu, H.; Jiao, J.A.; Sullivan, E.; Luke, T.; Davey, R.T., Jr. Safety and tolerability of a novel, polyclonal human anti-MERS coronavirus antibody produced from transchromosomic cattle: A phase 1 randomised, double-blind, single-dose-escalation study. Lancet Infect. Dis. 2018, 18, 410-418. [CrossRef]

16. Du, L.; Yang, Y.; Zhou, Y.; Lu, L.; Li, F.; Jiang, S. MERS-CoV spike protein: A key target for antivirals. Expert Opin. Ther. Targets 2017, 21, 131-143. [CrossRef] [PubMed]

17. Farag, E.; Sikkema, R.S.; Vinks, T.; Islam, M.M.; Nour, M.; Al-Romaihi, H.; Al, T.M.; Atta, M.; Alhajri, F.H.; Al-Marri, S.; et al. Drivers of MERS-CoV emergence in Qatar. Viruses 2018, 11, 22. [CrossRef] [PubMed]

18. Song, Z.; Xu, Y.; Bao, L.; Zhang, L.; Yu, P.; Qu, Y.; Zhu, H.; Zhao, W.; Han, Y.; Qin, C. From SARS to MERS, thrusting coronaviruses into the spotlight. Viruses 2019, 11, 59. [CrossRef]

19. Widagdo, W.; Sooksawasdi Na Ayudhya, S.; Hundie, G.B.; Haagmans, B.L. Host determinants of MERS-CoV transmission and pathogenesis. Viruses 2019, 11, 280. [CrossRef]

20. Yan, B.; Chu, H.; Yang, D.; Sze, K.H.; Lai, P.M.; Yuan, S.; Shuai, H.; Wang, Y.; Kao, R.Y.; Chan, J.F.; et al. Characterization of the lipidomic profile of human coronavirus-infected cells: Implications for lipid metabolism remodeling upon coronavirus replication. Viruses 2019, 11, 73. [CrossRef]

21. Adney, D.R.; van Doremalen, N.; Brown, V.R.; Bushmaker, T.; Scott, D.; de Wit, E.; Bowen, R.A.; Munster, V.J. Replication and shedding of MERS-CoV in upper respiratory tract of inoculated dromedary camels. Emerg. Infect. Dis. 2014, 20, 1999-2005. [CrossRef] [PubMed]

22. Yao, Y.; Bao, L.; Deng, W.; Xu, L.; Li, F.; Lv, Q.; Yu, P.; Chen, T.; Xu, Y.; Zhu, H.; et al. An animal model of MERS produced by infection of rhesus macaques with MERS coronavirus. J. Infect. Dis. 2014, 209, $236-242$. [CrossRef] [PubMed]

23. Adney, D.R.; Bielefeldt-Ohmann, H.; Hartwig, A.E.; Bowen, R.A. Infection, replication, and transmission of Middle East respiratory syndrome coronavirus in alpacas. Emerg. Infect. Dis. 2016, 22, 1031-1037. [CrossRef] [PubMed]

24. De Wit, E.; Prescott, J.; Baseler, L.; Bushmaker, T.; Thomas, T.; Lackemeyer, M.G.; Martellaro, C.; Milne-Price, S.; Haddock, E.; Haagmans, B.L.; et al. The Middle East respiratory syndrome coronavirus (MERS-CoV) does not replicate in Syrian hamsters. PLoS ONE 2013, 8, e69127. [CrossRef] [PubMed]

25. Raj, V.S.; Smits, S.L.; Provacia, L.B.; van den Brand, J.M.; Wiersma, L.; Ouwendijk, W.J.; Bestebroer, T.M.; Spronken, M.I.; van Amerongen, G.; Rottier, P.J.; et al. Adenosine deaminase acts as a natural antagonist for dipeptidyl peptidase 4-mediated entry of the Middle East respiratory syndrome coronavirus. J. Virol. 2014, 88, 1834-1838. [CrossRef] [PubMed]

26. Coleman, C.M.; Matthews, K.L.; Goicochea, L.; Frieman, M.B. Wild-type and innate immune-deficient mice are not susceptible to the Middle East respiratory syndrome coronavirus. J. Gen. Virol. 2014, 95, 408-412. [CrossRef]

27. Zhao, G.; Jiang, Y.; Qiu, H.; Gao, T.; Zeng, Y.; Guo, Y.; Yu, H.; Li, J.; Kou, Z.; Du, L.; et al. Multi-organ damage in human dipeptidyl peptidase 4 transgenic mice infected with Middle East respiratory syndrome-coronavirus. PLoS ONE 2015, 10, e0145561. [CrossRef]

28. Zhao, J.; Li, K.; Wohlford-Lenane, C.; Agnihothram, S.S.; Fett, C.; Zhao, J.; Gale, M.J., Jr.; Baric, R.S.; Enjuanes, L.; Gallagher, T.; et al. Rapid generation of a mouse model for Middle East respiratory syndrome. Proc. Natl. Acad. Sci. USA 2014, 111, 4970-4975. [CrossRef]

29. Li, K.; Wohlford-Lenane, C.L.; Channappanavar, R.; Park, J.E.; Earnest, J.T.; Bair, T.B.; Bates, A.M.; Brogden, K.A.; Flaherty, H.A.; Gallagher, T.; et al. Mouse-adapted MERS coronavirus causes lethal lung disease in human DPP4 knockin mice. Proc. Natl. Acad. Sci. USA 2017, 114, E3119-E3128. [CrossRef]

30. Widagdo, W.; Okba, N.M.A.; Richard, M.; de Meulder, D.; Bestebroer, T.M.; Lexmond, P.; Farag, E.A.B.A.; Al-Hajri, M.; Stittelaar, K.J.; de Waal, L.; et al. Lack of Middle East respiratory syndrome coronavirus transmission in rabbits. Viruses 2019, 11, 381. [CrossRef] 
31. Fan, C.; Wu, X.; Liu, Q.; Li, Q.; Liu, S.; Lu, J.; Yang, Y.; Cao, Y.; Huang, W.; Liang, C.; et al. A human DPP4-knockin mouse's susceptibility to infection by authentic and pseudotyped MERS-CoV. Viruses 2018, 10, 448. [CrossRef] [PubMed]

32. Chen, Y.; Rajashankar, K.R.; Yang, Y.; Agnihothram, S.S.; Liu, C.; Lin, Y.L.; Baric, R.S.; Li, F. Crystal structure of the receptor-binding domain from newly emerged Middle East respiratory syndrome coronavirus. J. Virol. 2013, 87, 10777-10783. [CrossRef] [PubMed]

33. Wang, N.; Shi, X.; Jiang, L.; Zhang, S.; Wang, D.; Tong, P.; Guo, D.; Fu, L.; Cui, Y.; Liu, X.; et al. Structure of MERS-CoV spike receptor-binding domain complexed with human receptor DPP4. Cell Res. 2013, 23, 986-993. [CrossRef] [PubMed]

34. Lu, L.; Liu, Q.; Zhu, Y.; Chan, K.H.; Qin, L.; Li, Y.; Wang, Q.; Chan, J.F.; Du, L.; Yu, F.; et al. Structure-based discovery of Middle East respiratory syndrome coronavirus fusion inhibitor. Nat. Commun. 2014, 5, 3067. [CrossRef] [PubMed]

35. Li, F. Structure, function, and evolution of coronavirus spike proteins. Annu. Rev. Virol. 2016, 3, $237-261$. [CrossRef] [PubMed]

36. Schindewolf, C.; Menachery, V.D. Middle East respiratory syndrome vaccine candidates: Cautious optimism. Viruses 2019, 11, 74. [CrossRef] [PubMed]

37. Zhou, Y.; Yang, Y.; Huang, J.; Jiang, S.; Du, L. Advances in MERS-CoV vaccines and therapeutics based on the receptor-binding domain. Viruses 2019, 11, 60. [CrossRef]

38. Adney, D.R.; Wang, L.; van Doremalen, N.; Shi, W.; Zhang, Y.; Kong, W.P.; Miller, M.R.; Bushmaker, T.; Scott, D.; de Wit, E.; et al. Efficacy of an adjuvanted Middle East respiratory syndrome coronavirus spike protein vaccine in dromedary camels and alpacas. Viruses 2019, 11, 212. [CrossRef]

39. Wang, Y.; Tai, W.; Yang, J.; Zhao, G.; Sun, S.; Tseng, C.K.; Jiang, S.; Zhou, Y.; Du, L.; Gao, J. Receptor-binding domain of MERS-CoV with optimal immunogen dosage and immunization interval protects human transgenic mice from MERS-CoV infection. Hum. Vaccines Immunother. 2017, 13, 1615-1624. [CrossRef]

40. Veit, S.; Jany, S.; Fux, R.; Sutter, G.; Volz, A. CD8+ T cells responding to the Middle East respiratory syndrome coronavirus nucleocapsid protein delivered by vaccinia virus MVA in mice. Viruses 2018, 10, 718. [CrossRef]

41. Zhao, G.; He, L.; Sun, S.; Qiu, H.; Tai, W.; Chen, J.; Li, J.; Chen, Y.; Guo, Y.; Wang, Y.; et al. A novel nanobody targeting Middle East respiratory syndrome coronavirus (MERS-CoV) receptor-binding domain has potent cross-neutralizing activity and protective efficacy against MERS-CoV. J. Virol. 2018, 92, e00837-18. [CrossRef] [PubMed]

42. He, L.; Tai, W.; Li, J.; Chen, Y.; Gao, Y.; Li, J.; Sun, S.; Zhou, Y.; Du, L.; Zhao, G. Enhanced ability of oligomeric nanobodies targeting MERS coronavirus receptor-binding domain. Viruses 2019, 11, 166. [CrossRef] [PubMed]

43. De Wilde, A.H.; Jochmans, D.; Posthuma, C.C.; Zevenhoven-Dobbe, J.C.; van Nieuwkoop, S.; Bestebroer, T.M.; van den Hoogen, B.G.; Neyts, J.; Snijder, E.J. Screening of an FDA-approved compound library identifies four small-molecule inhibitors of Middle East respiratory syndrome coronavirus replication in cell culture. Antimicrob. Agents Chemother. 2014, 58, 4875-4884. [CrossRef]

44. Han, H.J.; Liu, J.W.; Yu, H.; Yu, X.J. Neutralizing monoclonal antibodies as promising therapeutics against Middle East respiratory syndrome coronavirus infection. Viruses 2018, 10, 680. [CrossRef] [PubMed]

45. Xia, S.; Lan, Q.; Pu, J.; Wang, C.; Liu, Z.; Xu, W.; Wang, Q.; Liu, H.; Jiang, S.; Lu, L. Potent MERS-CoV fusion inhibitory peptides identified from HR2 domain in spike protein of bat coronavirus HKU4. Viruses 2019, 11, 56. [CrossRef] [PubMed]

46. Wang, C.; Hua, C.; Xia, S.; Li, W.; Lu, L.; Jiang, S. Combining a fusion inhibitory peptide targeting the MERS-CoV S2 protein HR1 domain and a neutralizing antibody specific for the S1 protein receptor-binding domain (RBD) showed potent synergism against pseudotyped MERS-CoV with or without mutations in RBD. Viruses 2019, 11, 31. [CrossRef] 
47. Jiang, Y.; Li, J.; Teng, Y.; Sun, H.; Tian, G.; He, L.; Li, P.; Chen, Y.; Guo, Y.; Li, J.; et al. Complement receptor C5aR1 inhibition reduces pyroptosis in hDPP4-transgenic mice infected with MERS-CoV. Viruses 2019, 11, 39. [CrossRef] [PubMed]

48. Liang, R.; Wang, L.; Zhang, N.; Deng, X.; Su, M.; Su, Y.; Hu, L.; He, C.; Ying, T.; Jiang, S.; et al. Development of small-molecule MERS-CoV inhibitors. Viruses 2018, 10, 721. [CrossRef] [PubMed]

(C) 2019 by the authors. Licensee MDPI, Basel, Switzerland. This article is an open access article distributed under the terms and conditions of the Creative Commons Attribution (CC BY) license (http://creativecommons.org/licenses/by/4.0/). 